\title{
Nature, Nation and the Dam. Narratives about the Harnessed Waterfall in Early Twentieth-Century Sweden
}

Fabian Zimmer

HCM 7: 171-208

DOI: $10.18352 / \mathrm{hcm} .553$

\begin{abstract}
When the first large-scale hydroelectric power plants were built in Sweden at the beginning of the twentieth century, the waterfall became a twofold symbol of the Swedish nation. On the one hand, the harnessed waterfall promised unlimited energy and economic growth, and thus turned into a unifying symbol of a national productive landscape. On the other hand, the unharnessed wild waterfall, to be enjoyed by tourists seeking refuge from the modern industrial world, became a symbol of a national recreational landscape. This situation, however problematic, did not result in conflict. Taking a look at the first two state-built water power plants in Sweden, I trace how the two contrasting concepts of landscape were harmonized within public discourse. I demonstrate how engineers, architects, conservationists, tourist organisations, and journalists together produced a broad public acceptance of the drastic changes in the national landscape brought about by the construction of these power stations.
\end{abstract}

Keywords: architecture, landscape, Sweden, technological sublime, waterfall, water power 


\section{Introduction. A Remarkable Death ${ }^{\mathrm{I}}$}

In November 1922, a 'remarkable death' occurred 'all quietly ... without the slightest reaction from the Swedish public': the waterfalls at Trollhättan fell silent. ${ }^{2}$ Due to a concurrence of low water levels in Lake Vänern, the reservoir of the Trollhättan water power plant, and high electricity demand, Sweden's largest river, the Göta Älv, ran dry on a stretch of about one kilometre. In place of the country's most famous waterfalls there was only bare rock. The public indifference in the face of the waterfall's 'death' led Thor Högdahl, the secretary of the Swedish Society for Nature Conservation (Svenska Naturskyddsföreningen, SNF), to cry out: 'Might it not be about time that we, here in Sweden ... start to ponder just a little on the great national and social importance of the protection of nature and cultural heritage before it is too late and our most precious natural and cultural values have already been sacrificed to Moloch?'3

While Högdahl was certainly among the most vociferous opponents to technological encroachments on the landscape during his time, he shared an appreciation of landscape as something of "national importance' with most of his contemporaries in the SNF and beyond. Since the late nineteenth century, early tourists, scientists and adventurers had discovered, mapped and made Sweden's nature accessible to a broadening public. The Swedish Tourist Association (Svenska Turistföreningen, STF), which was founded in I 885 and had grown into a veritable popular movement by the I9IOs, was a central actor in popularizing the idea that sublime places, like the glaciers and tops of the Swedish mountains, and especially the large Swedish waterfalls, were a national asset that should be known and cherished by every Swede. ${ }^{4}$ Thus, when the first tangible plans to exploit the falls at Trollhättan emerged in I894, the occasional criticism raised on the part of the Tourist Association was cast in a nationalist rhetoric. In I 896, one writer in the Association's yearbook urged all who engaged in the question of Trollhättan's exploitation to be 'patriotic enough not to harm this pure jewel of Sweden!'s

When the inauguration festivities in Trollhättan took place on 28 October I9IO, the new power station was presented and perceived in a no less nationally spirited manner. Trollhättan was the first power plant built by the Swedish State Power Board (Kungliga Vattenfallsstyrelsen, later to become Vattenfall $A B) .{ }^{6}$ And although contemporary commentators complained that the inauguration took place "without official 
pageantry', the Swedish King Gustav V visited Trollhättan for the first time on this occasion and the whole city had 'a rich and waving blue-yellow attire, garnished with festoons, honour portals etc.' Representatives of the State Power Board as well as other state representatives and local politicians also came to inspect the new power plant, and the whole select company was greeted by 'a large crowd and school children in the market place with flags in their hands - a very appealing group', as one newspaper reported. ${ }^{7}$

The festivities were equally spectacular when Porjus, the second water power plant built by the State Power Board, was inaugurated in I9I5 - at least considering that the event took place during winter in the very far north of Sweden, at the waterfalls of Porjus that a few years earlier had been largely unknown. This time too, commentators held that the inauguration was 'celebrated in very simple forms' - an understatement that may have served mainly to glorify the completion of the power plant all the more. ${ }^{8}$ And indeed, this time the King was not physically present. Instead, he gave the signal to start the machines 'by pressing on the contact button' that had been installed in the royal castle in Stockholm and that was connected by a cable to an 'electric siren in the machine hall'.${ }^{9}$ The event was accompanied by several film teams, who tried to shoot "clear and good images for the edification of the whole world's cinema audience. ' ${ }^{\prime \prime}$ The electrically mediated presence of the King and the cinematographically mediated presence of a world audience not only testified to the importance of the event but also to its modernity. The fact that the event was a deeply national festivity was made clear by State Counsellor Oscar von Sydow in his inauguration speech: 'We stand before the accomplishment of a remarkable feat that rises in the midst of the wastelands as a stately monument to Swedish enterprise, Swedish engineering genius, and Swedish determination.'

As these few glimpses into the source material demonstrate, public imagination in Sweden around I900 conceived of the waterfall as a twofold symbol of the nation. On the one hand, the concentrated height difference found at the waterfalls of Sweden could be used to produce electricity at relatively low costs, which would make the country independent from coal imports and instil a much needed vigour into domestic industry - so it was hoped. The waterfall therefore turned into a symbol of an emerging national productive landscape. On the other hand, 
the unharnessed waterfall became a symbol of a national recreational landscape. The wild and unspoiled waterfall represented a refuge from the modern industrial world, where authentic Swedishness could be experienced by Swedish and international tourists alike. According to Orvar Löfgren, from whom I borrow this taxonomy, these two diverging perceptions of landscape emerged as a modern mode of perception that superseded an older, pre-modern mode, in which there was only one magical landscape, populated by supernatural beings that accompanied work, leisure and all other activity performed in the landscape. ${ }^{12}$

However, in the Swedish discourse on early water power plant constructions this antithetical constellation did not result in conflict, as one might expect, even though it was considered to be highly problematic. In fact, the time period I am examining here, the thirty years between the beginning of the debates on the exploitation of waterfalls by the State in I894 and Högdahl's protest in I923, were characterized by an almost complete absence of protest against the encroachments on the landscape. This circumstance has led historians to conclude that 'Water power was somehow perceived as standing outside or above all parties' ${ }^{13}$ - a statement that is certainly correct, but falls short of approaching the question of how this general consent about the industrial remaking of Sweden's waterfall landscapes came into being. ${ }^{I 4}$

In the following, I will trace in a detailed analysis of the source material how engineers, architects, artists, nature protection organizations, tourist organizations and journalists together engendered broad public acceptance of the drastic changes in the national landscape brought about by the construction of these power plants. Drawing on case studies of the two first state-built power plants in Sweden, Trollhättan and Porjus, I will demonstrate how the two contrasting national landscapes were harmonized in public discourse. I build my argument in four steps. The first part starts from the contrasting conceptions of landscape outlined above, but shows how they were integrated into narratives that highlighted the improvement and civilization of waterfall landscapes through the construction of the power plants. In the second part, I show how continuity, rather than contrast, most often structured the interpretations of the new landscapes formed by the water power plants. This continuity between waterfall and water power landscapes was most usually framed in the mode of the sublime, as I demonstrate in the third part. In the fourth and final part, I show that the sublime 
made it possible to inscribe the water power landscapes into a rhetoric of national unification, in which the national symbolism of the recreational landscape and the productive landscape in fact amplified each other.

\section{Civilizing Landscapes}

At the turn of the century, Trollhättan was a tourist place. At the falls of Trollhättan, so the I889 English edition of Karl Baedeker's Handbook for travellers to Norway and Sweden warned its readers, '[t]he traveller's patience will be severely tried by the numerous dealers in photographs and other small objects.' ${ }^{15}$ A few years later, in I896, a local section of the STF was set up in Trollhättan. It was funded by the local authority and by individuals and charged with taking 'rather extensive measures to make Trollhättan's beautiful nature more accessible to tourists' in order 'to lead the stream of tourists to Sweden.' This included among other things the construction of new paths, the publication of a map and the organization of the 'cicerone services' ${ }^{16}$ In the same year, Gustaf Retzius, an anthropologist and professor of anatomy, visited the falls at Trollhättan and published an account of his visit in the STF's yearbook. The commercial hustle and bustle at the waterfall was not an issue in his account. Instead he gave what one could read as an instruction for other visitors on how to explore the area around the waterfalls appropriately, 'because it is singular about Trollhättan that its beauties are situated in various places, and should be seen from many different points. ${ }^{17}$ His account is a prime example of the sublime experiences that the romantically spirited tourists of the late nineteenth century sought in places like Trollhättan: 'It is a magnificent sight. The longer one stays, the more one experiences something of the peculiar spell that is reported in the old legends; something of the simultaneously appealing and terrifying charm with which the forces of nature in their untamed immenseness affect the human senses. ${ }^{18}$

But at the turn of the century Trollhättan was not only a tourist place, a recreational landscape, but also most clearly a productive landscape. When the first initiatives to build a large water power plant in the falls of Trollhättan emerged in the I88os, smaller mills had already for centuries used the waterfall's mechanical energy. After the construction of 
a canal around the waterfalls, which was later integrated into the Göta Canal connecting the North Sea with the Baltic Sea, the settlement at the waterfalls experienced a strong economic upswing during the nineteenth century. The enterprises that mainly established themselves near the waterfall were sawmills and other wood-working industries. ${ }^{19}$

Almost simultaneously with the first plans to exploit the waterfall on a large scale the first concerns were raised and it was demanded that the exploitation take care of the waterfall's beauty. These demands showed a strong sense of the contradiction between the industrial and the tourist landscape; however, their tone was usually rather optimistic. Retzius, once more, claimed that

if waterfalls are to preserve their beauty, it is necessarily required that they may keep their original framework unspoiled by human hands. Industrial plants and installations distort it easily. There is, however, hope that the future shall give consideration to this. It should not be impossible to unite the requirements of usefulness with those of natural beauty. Let us hope that this can happen! $!^{20}$

His call was repeated, often in exactly the same wording, in various quarters. Not only representatives of the $\mathrm{STF}^{21}$ but also the engineers who engaged in the planning of a potential power plant held that it would be a pity if the scenic falls were deprived of all water. Because regardless of the aesthetic point of view, in itself not insignificant, keeping a moderate amount of water in the falls could also be valued in money.' To prove his argument, Fredrik Vilhelm Hansen, the author of these words who would become head of the State Power Board just a few years later, pointed to some statistics on the tourist traffic at the Trollhättan falls. ${ }^{22}$

When the power plant was eventually constructed and taken into operation in I9I0, apparently all hopes were satisfied, if we believe the enthusiasm expressed in a whole range of publications. The engineers who had planned the power station congratulated Erik Josephson, the architect hired to design the plant's façade, on his design of the machine hall, which gave a 'particularly fortunate impression' and connected 'admirably well to the landscape'. ${ }^{23}$ Josephson on his part praised the fact 'that the engineers ... have rendered an outstanding service by violating nature as little as possible, and, where it still had to 
happen, have succeeded in remedying the damages through ingenious arrangements. ${ }^{24}$ However, those who were most vocal about the successful handling of the constructions at Trollhättan were the representatives of the STF and, even more so, of the newly founded SNF. For instance, Thor Högdahl added a note to an article on 'The exploitation of watercourses and the protection of nature's beauty' in the SNF's yearbook of I9I I, in which he emphasized that upon inspecting the plant at Trollhättan the directorate of the SNF had found that 'genuine consideration and even expenses have been raised to make the arrangements as aesthetically appealing as possible. ${ }^{25}$

Remarkably often commentators interpreted the new landscape not only as successfully conserved but even as an improved landscape. Before the construction of the power plant, the bluffs on the waterfall had been brimming with industrial buildings that had been a nuisance to many a tourist. Gustav Retzius, to cite one of them, was not fundamentally critical of the industrial and commercial businesses in Trollhättan, as he passed several of them during his strolls around the waterfalls without at least taking any negative note of them. The canal and the locks even appealed to him as 'highly interesting'. It was only in the proximity of the waterfall that the traces of human activity began to encroach on Retzius' enjoyment of the landscape: 'The view from King's Bridge is magnificent, but it is not insignificantly disrupted by the ugly buildings of the pulp factory situated nearby on the eastern bank.' The sight of these constructions made him wish himself 'back to the time when "civilization" had not yet made its home here and these islands as well as the opposite bank were still overgrown with their wild, primeval forest. ${ }^{26}$ However, as we can see from his interest in the canal infrastructure, it was not the presence of 'civilization' per se that troubled his enjoyment of nature - it was the fact that it lacked an overall aesthetic plan. As several commentators emphasized, it was the engagement of the State which would constitute a 'strong guarantee against unnecessary vandalism' caused by private building activity. ${ }^{27}$ After the construction of the power plant and the removal of some of the disturbing buildings, this discourse persisted. Looking back in a lecture held in I9I4, Karl Starbäck, a botanist and committed member of the SNF, found that 'The private industrial establishments that have subsequently been built [during the nineteenth century] in order to exploit the power of water are unusually successful examples of how 
one should not build and must not build if one has the slightest feeling for nature or even aesthetic values'. By contrast, the power plant that replaced these constructions represented 'a good example' ${ }^{28}$

It is illuminative at this point to shift perspective and to examine the discourse on the power plant built at Porjus between I9Io and I9I5. Unlike Trollhättan, with its canals, locks and industrial establishments, Porjus had a much less obvious pre-history of landscape change and concerns about the aesthetic implications of exploitation were rarely part of public debates. When in I908 the first engineers of the State Power Board came to explore the place, they found a small homestead near the fifty metre high waterfalls in the Lule Älv, inhabited by a settler household of eight persons. Only a $50 \mathrm{~km}$ footpath over the mires connected the place with Gällivare, the nearest train station. Nevertheless, the place was well frequented by travellers and tourists who were either hiking north to the famous waterfalls of Stora Sjöfallet, which were protected as Sweden's first national park in I909, or south to the equally renowned falls of Harsprånget, both in the Lule river system. To meet this increasing demand, Erik Abraham Olsson, the Sámi owner of the homestead, had only just built another house for accommodation when the construction of the power plant started in I9IO. Furthermore, the wider area around Porjus was used by Sámi herders as migratory route and grazing ground for their reindeers. ${ }^{29}$

This cultural landscape eluded the attention of contemporary commentators almost completely, who for the most part lived thousand or more kilometres further south and for whom Norrland, the northern half of the Swedish territory, was largely a terra incognita..$^{30}$ Blank spots on their mental maps were filled by imagination, and the stories that were told about the modernization of Sweden were nowhere bolder than here. As historian Sverker Sörlin has demonstrated, around I900 Norrland was simultaneously discovered as a land of the future, where enormous economic promise lay slumbering in unexploited forests, ore deposits and waterfalls, and as an ancient land, where seemingly untouched nature and supposedly primitive Sámi culture could still be found. ${ }^{31}$ It was this ancient land that Karl-Erik Forsslund, one of the most radical preservationists of his time, sought to defend. In the only article that openly opposed the construction of the power plant in Porjus, he asked (in italics): 'But this regulation [of the river] - must it 
not be absolutely prevented and forbidden by all means and under all circumstances?'32

Forsslund's outburst remained an exception, however. For most commentators concerns about the natural beauty of the landscape at Porjus were of little urgency. Unlike Trollhättan, the falls here had not been a tourist attraction for centuries, and the encroachment on the landscape was dwarfed by the perceived immensity of the remaining 'wasteland'. The typical depiction of the landscape was thus more in line with an article by the Stockholm journalist Eira Hellberg, who had certainly never seen the place with her own eyes. She told the history of Porjus as a 'piece of Swedish cultivation history' and based it on a dramatic contrast. ${ }^{33}$ She described the land around Porjus as a completely empty space "where no fish lives and no boat is oared ... where not even the reindeers advance'. The Sámi living in the area only figured in her account briefly, as 'small brown men and women', part of 'the dying people'. Seen against this foil, the construction of Porjus power plant could shimmer magnificently. The engineers and workers had 'conquered Lappland's marrow foot by foot and thrown a Deed [sic] into the land of millennial waiting.' ${ }^{34}$

This rhetoric of the conquest of wilderness was ubiquitous in the imagery surrounding Porjus. Its most artful manifestation is perhaps found in the architectural design that Erik Josephson gave to the façade of the large building that housed switchgear and control rooms. Josephson's employers, who had hired him again for Porjus after his accomplishments in Trollhättan, described his design in rather prosaic terms: 'The switchgear building is executed in brick with a frost-resistant brick facework from Helsingborgs Ångtegelbruk Incorporated, on a base of raw granite. ${ }^{35}$ It is only at second sight that this seemingly straightforward description reveals what in fact can be read as a symbolic programme in the façade's design. Elevated above, and 'dominating' the 'wild' waterfall (according to many commentators), ${ }^{36}$ resting on a base made from 'raw' granite that was followed above by the man-made, burnt brick, which additionally was resistant to nature's forces, the whole structure finally tapered into a tower that culminated in a golden crown, the symbol of the Swedish monarchy, of the state and ultimately of the whole nation. The vertical order of symbolic refinement embodied in the façade paralleled and commented the technical process of refinement taking place within the power station. There, the power of wild water was transformed into 
a rotation movement and further into electric energy in the machine hall fifty metres below the ground, then transported above ground into the switchgear building, where it was transformed (in the electrotechnical sense) to high voltage and from there fed into the transmission lines (Figs. I and 2). Thus, the production of electricity was ennobled as a way of cultivating, or civilizing, an otherwise unused and purposeless place. Against this background aesthetic concerns about the landscape apparently lost their importance.

As we can see, the discourse about landscape change took quite different paths in Porjus and Trollhättan. The changes in the landscape in Trollhättan were conceptualized as a complex problem that needed to be approached very carefully, while the very same problem of the two diametrically opposed landscapes in Porjus rather served to dramatize, not to criticize the encroachments on the landscape. Still, there is a common thread connecting the two different interpretations of the encroachment on the landscape in Trollhättan and Porjus. In both cases they could be understood as an improvement of the landscape through civilization. In Porjus, as we have just seen, as the cultivation of wilderness; in Trollhättan as a revised civilization, as the removal of the traces of uncontrolled capitalist individualism and their replacement by a more cultivated, well-planned landscape.

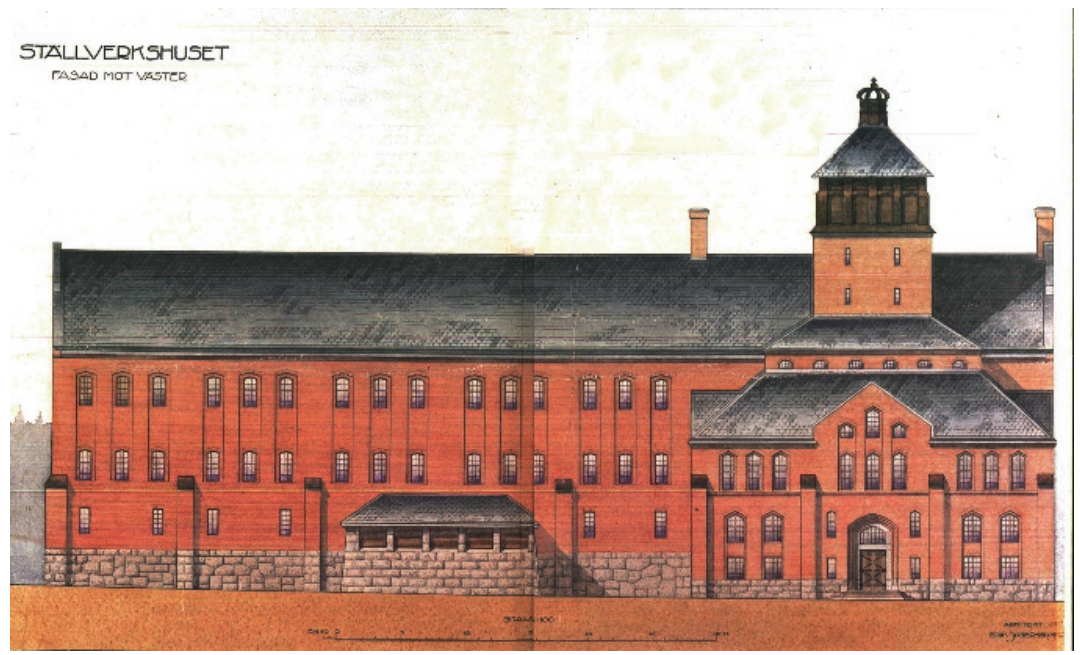

Figure I 'The switchgear building. Western façade.' From: Forsgren, Porjus, back endpaper. 


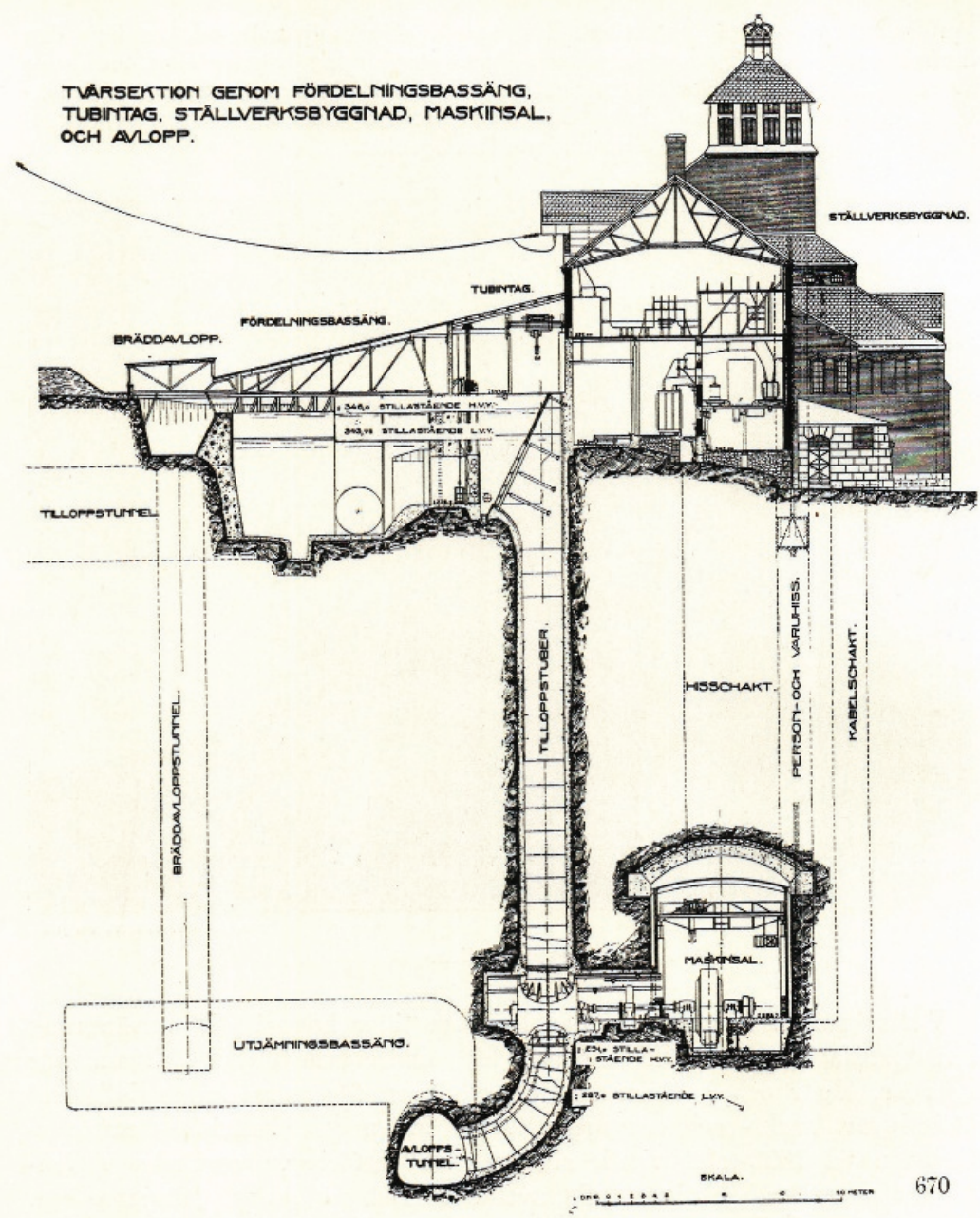

Figure 2 'Section through distribution basin, intake, switchgear building, machine hall and discharge tunnel.' From: Hansen, 'Sveriges Vattenfall', 302.

\section{The Persistence of Landscape}

Perhaps more than the idea of cultivation, another circumstance shaped the positive and consensual appropriation of the new landscapes at the harnessed waterfalls and allowed contemporaries to harmonize the different conceptions of landscape. After the opening of both plants, the familiar waterfall landscapes persisted for a while. At Trollhättan it 
was only in I922 that the waterfall first ran dry; in Porjus, where water discharge was much more irregularly distributed over the year, it took several lake regulations and plant extensions until even the peaks in water discharge could be processed in the power plant and no longer flowed through the old riverbed. As Eva Jakobsson has noted, water power companies in Sweden started to celebrate 'Falls Day' from the late I950s on, letting the harnessed waterfalls run free for a few hours in front of a thrilled audience, as 'a new marketing strategy' to appease ecological protest against water power. ${ }^{37}$ Such an iconography of flowing water existed already in the I9IOs, but it was not by propagandistic choice but by necessity that the waterfalls continued to run free. Until I9I 8 the Swedish water law prohibited the damming of rivers, making it illegal to regulate the rivers' discharge.$^{38}$ Therefore, the power plants planned during this period were dimensioned to process the expected minimum discharge of the corresponding river. And when the new water law of I9I 8 permitted the regulation of rivers, in most cases the power stations were not immediately outfitted with the required capacity to use up all water. The water remaining in the river bed was integrated into an iconography of flowing water that helped foster further acceptance of the encroachment on the landscape by reconciling nature and technology as well as by highlighting the persistence of landscape.

In this vein, images like the book vignette that the State Power Board had commissioned from the renowned artist Arthur Sjögren to illustrate the chapters on Trollhättan's power plant in several of its publications, ${ }^{39}$ presented the plant and the waterfall in harmonious coexistence (Fig. 3). Another good example of this can be found in a photograph of the power station and the waterfall next to one another, all neatly framed by coniferous trees that almost completely hid the technical constructions (Fig. 4). The image was first published in I9I 2 in an article in Teknisk Tidskrift, the central organ of the Swedish engineers, with the caption reading 'View of the machine hall at Trollhättan's power plant'.$^{40}$ It was reprinted in a General description of the State power plants in Sweden, issued by the Power Board in I92 I, and here the caption read: 'Trollhättan. The Helvete falls', designating the lowest section of the waterfall that was seen in the photograph. ${ }^{41}$

In the case of Porjus, it was less the coexistence of nature and the plant that was portrayed, but rather their interpenetration. For the inauguration at Porjus guests were handed a programme leaflet, also 


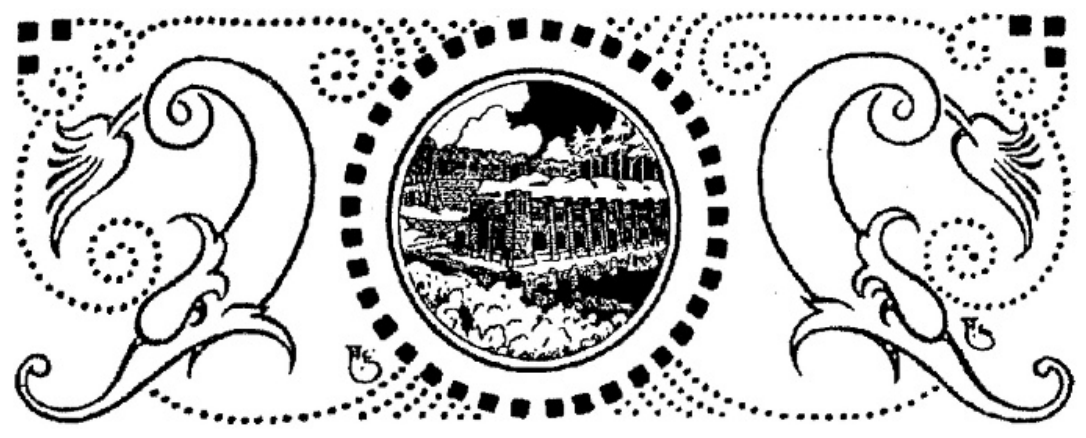

Figure 3 Book vignette for Trollhättan by Arthur Sjögren. From: Königliche Wasserfallverwaltung (ed.), Die Staatlichen Kraftwerke Schwedens I92 I, II.

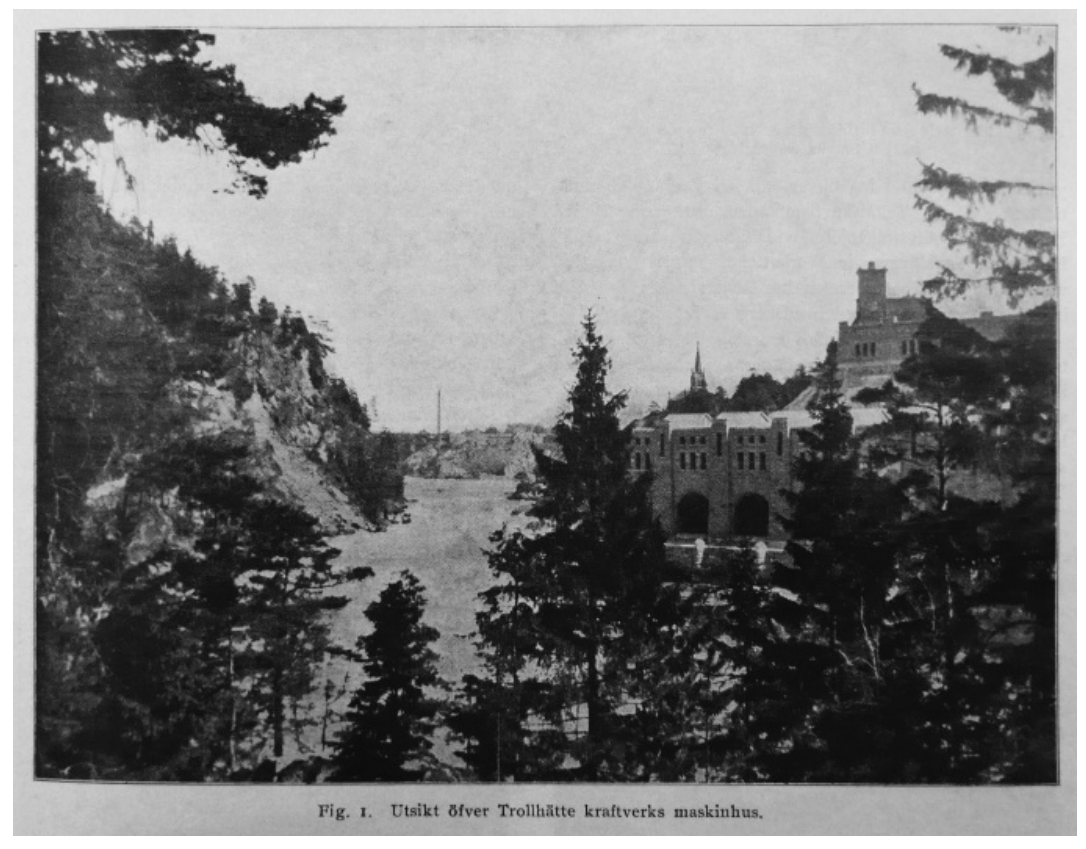

Figure 4 'View of the machine hall at Trollhättan's power plant'. From: H[olmberge]r, 'Trollhättan just nu', 207.

designed by Arthur Sjögren, which was emblazoned by a depiction of the wild Porjus waterfall running over the dam, the whole view, here again, nicely framed by trees (Fig. 5). The representation was quite 


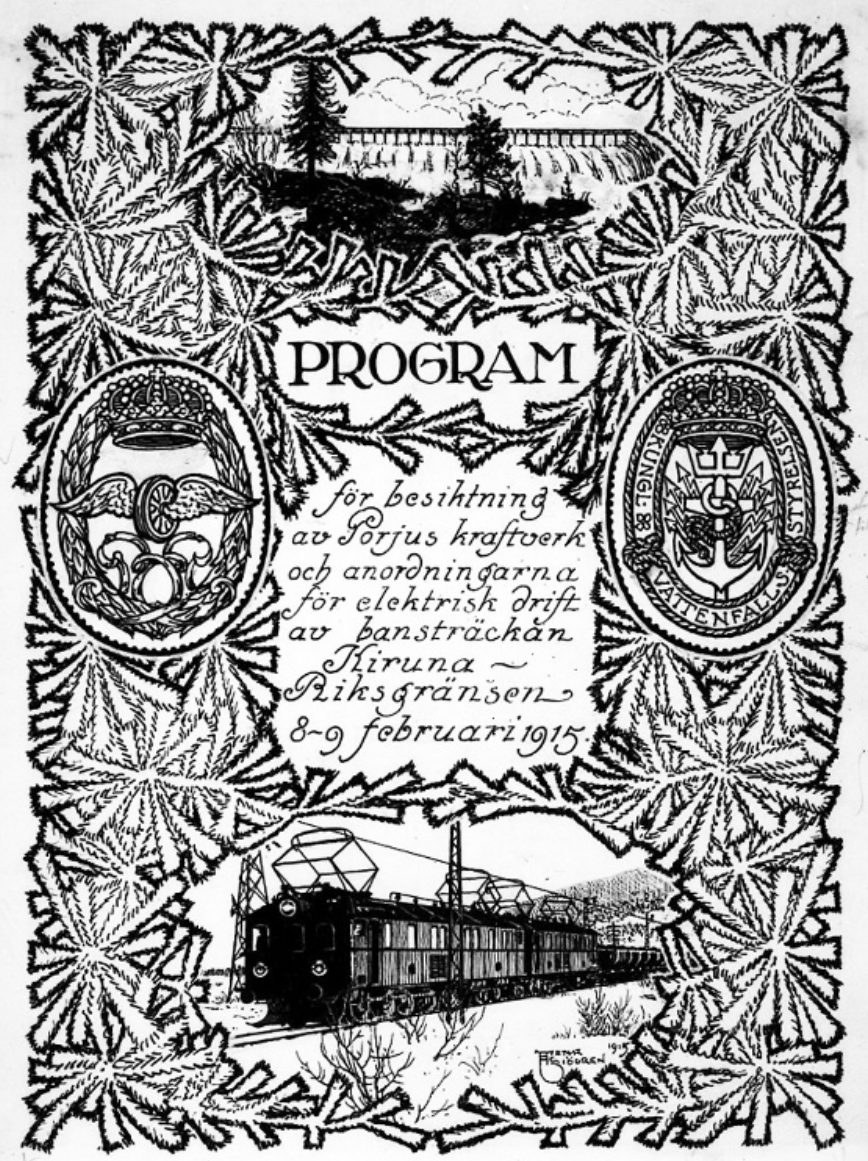

Figure 5 'Programme of the inspection of Porjus power plant and the installations for electrical operation on the railway line Kiruna-Riksgränsen. 8-9 February, I9I5.' From: historia.vattenfall.se/sv/media-archive/image (29.0I.20I9).

accurate: the dam at Porjus was partly built as an Ambursen dam, over which excess water could flow off; a design that was often praised, as it appeared to be 'shaped perfectly according to water's most natural fall' ${ }^{42}$ Something else can be observed in Sjögren's program leaflet. It was not only the amalgamation of waterfall and power plant that was given form here; Sjögren also postulated a continuity of landscape by depicting the dam with a striking resemblance to a frequently circulated 


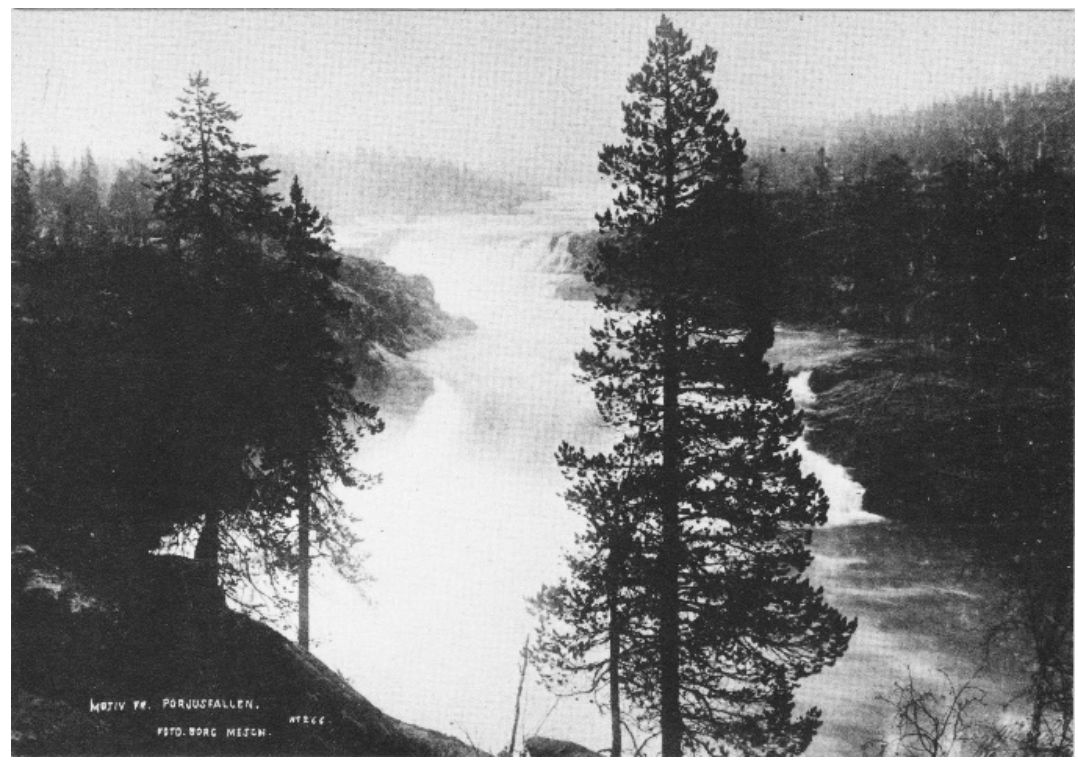

Figure 6 'Motive fr. the Porjusfalls. Photo. Borg Mesch'. Here in a reproduction on a postcard.

photograph of the waterfall that had been taken by the photographer Borg Mesch before construction had begun (Fig. 6).

Be it by emphasis on the coexistence, on the interpenetration or even on the continuity of waterfall and power plant, the persistence of the waterfall landscape constituted a strong mitigation for those critical towards the exploitation, as it was only a 'negligible fraction' of the falls that had been taken into use. ${ }^{43}$ Taken together with the improvement of landscape, the new power plants could thereby easily be integrated into the familiar touristic landscape of recreation. Accordingly, Göteborgs-Posten noted on the inauguration day of the power plant: 'Apropos tourists, it has turned out that the power plant has deterred them from travelling to Trollhättan to such a minor degree that it has on the contrary, as far as one can judge, acted as another attraction to the place.' ${ }^{44}$ Never had as many tourists visited Trollhättan within one year, the article claimed. And also in Porjus the constructions' effect on tourism was found to be very positive. In I9I4, the STF awarded a gold medal to Axel Granholm, an 'interested and vigorous promoter of the tourist services in Lappland'. The engineer Granholm had primarily 
led the construction works at Porjus power plant, but had simultaneously engaged in 'the execution of all facilities of the [Swedish Tourist] Association along the Lule Älv'. ${ }^{45}$

But it soon turned out that not only the traces of the productive landscape could be integrated into the natural landscape of recreation, enjoyed by nature lovers of all shades, but also the other way round. The touristic mode of seeing and being in the landscape could also be extended into the power plant. At the easily accessible installations at Trollhättan, tourists were welcomed into the power station: A "'spectator gallery", to which access is gained without passing through the machine hall' had been integrated into the design of Trollhättan's machine hall. ${ }^{46}$ It had no other function than to render the machines accessible to the curious gaze of the tourist. The success of this installation is manifest in a report of an automobile trip through western Sweden that was published in the magazine Vecko-Journalen in I9I2. The modern car travellers took a short stop at Trollhättan's waterfall, enjoying 'a view that never gets old': the view of a sublime waterfall, 'an unleashed lightning that runs eternally, it cooks and boils with wild force ... and it is as if something strangely magic and alluring sang out of the swirls.' The travellers continued their trip into the power station, where the very same experience of the sublime struck them: 'It is a

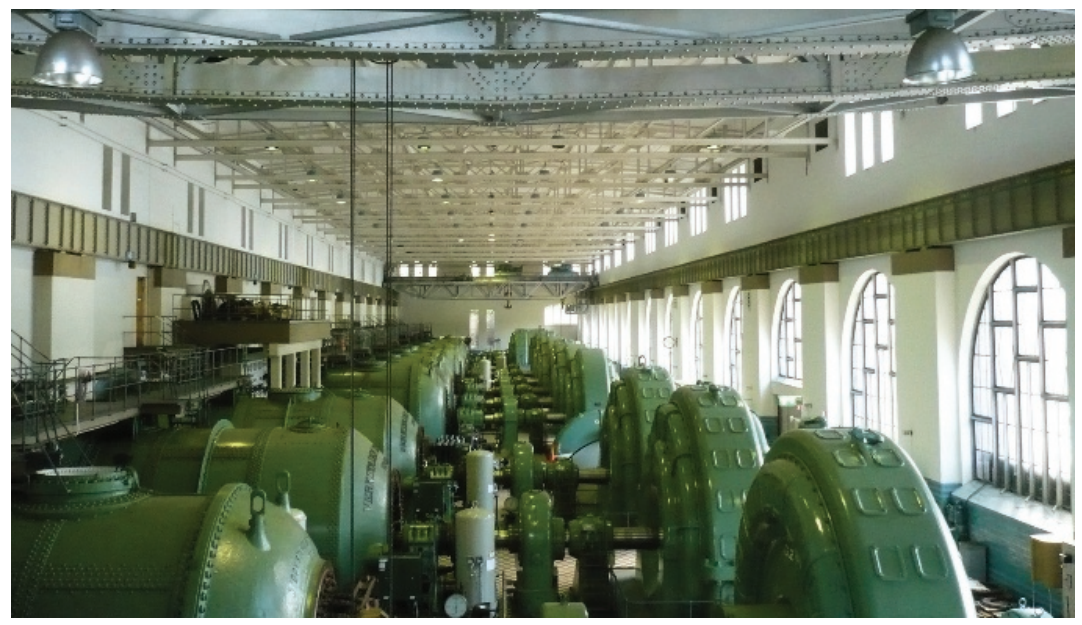

Figure 7 The machine hall in Trollhättan, seen from the spectator gallery. Photograph by the author, 2015. 
magnificent sight one has, standing up on the gallery looking down into the hall .... The power and the greatness speak just as loud in here as they just did in the sizzling water whirls.' ${ }^{47}$ (Fig. 7).

\section{Manifestations of the Sublime}

I have pointed out before that the waterfalls of Sweden had come to be perceived as sublime places by the end of the nineteenth century. We may just re-evoke Retzius' experience at the waterfalls of Trollhättan, which he found 'simultaneously appealing and terrifying', for something of a minimal definition of the sublime..$^{8}$ In the descriptions of waterfalls published by the STF and other nature lovers, a vast imagery was developed with which the sudden experience of the sublime could be verbalized; an imagery that was populated by magic creatures and surrounded by a sacral aura. Accordingly, Retzius saw the shapes of 'fantastical monstrosities and trolls ... of fairies and fair, shimmering mystical creatures' emerging from the waters. The idea that the waterfall was a sacred place, rather implicit in Retzius' text, was for instance expressed in the oftrepeated notion that the harnessing of the waterfalls should be undertaken with 'piety'. ${ }^{49}$ Both aspects - the association with magical creatures and sacralization - came to play a vital role in the imagery of water power stations, conceptualizing them as sublime places, just like the waterfall.

Let us first consider the metaphor of the sacral. It belonged almost inescapably to the standard repertoire in any description of water power stations, and was often transported by adjectives like 'grand' or 'powerful', emphasizing the physical immenseness of the constructions..$^{5^{\circ}} \mathrm{But}$ it did by no means stop there. For example, in one description of the machine hall at Trollhättan, Gösta Malm, the engineer who had headed its construction, wrote:

The erected building ... consists of three parts: a central nave over the turbines and generators, or the so-called machine hall, a rear, housing accumulators along with the cable vault and main switch, and finally premises for the storing and cleaning of oils, telephone room etc. and a vaulted road bridge running over the outlet in front of the nave. ${ }^{51}$

The repeated identification as a 'nave' and the qualification of the term 'machine hall' as 'so-called' justify seeing the metaphor as a conscious 
choice rather than an accidental slip, and taken together with the reaction of the automobile travellers quoted above there is good reason to believe that Malm was not the only one who perceived the machine hall as a church building.

In the case of Porjus, this nexus was even more evident. Josephson, the architect, did not shy away, to say the least, from taking inspiration from sacred architecture in his design for Porjus. Not only the monumental overall shape and the tower at one end of the building referred to religious architecture but also the details in the structure's main body, such as the rhythmical arrangement of lancet windows and hinted buttresses or the small steps in the roof structure suggesting a three-nave basilica (Figs. I and 8)..$^{52}$ It is no wonder that from the day of its inauguration the building went by the name of 'Porjus cathedral'. ${ }^{53}$

Yet, it was the machine hall at Porjus, lying fifty metres below the 'cathedral' ('surely the largest crypt that there is', as one commentator reckoned), ${ }^{54}$ that inspired the most dramatic portrayals in the mode of the sacral (Fig. 9). A journalist of the north Swedish socialist newspaper Norrskensflamman, who called himself 'Per-Johan', wrote a series of witty articles on the inauguration of the plant at Porjus. It might have been due to his political orientation that he described the machine hall

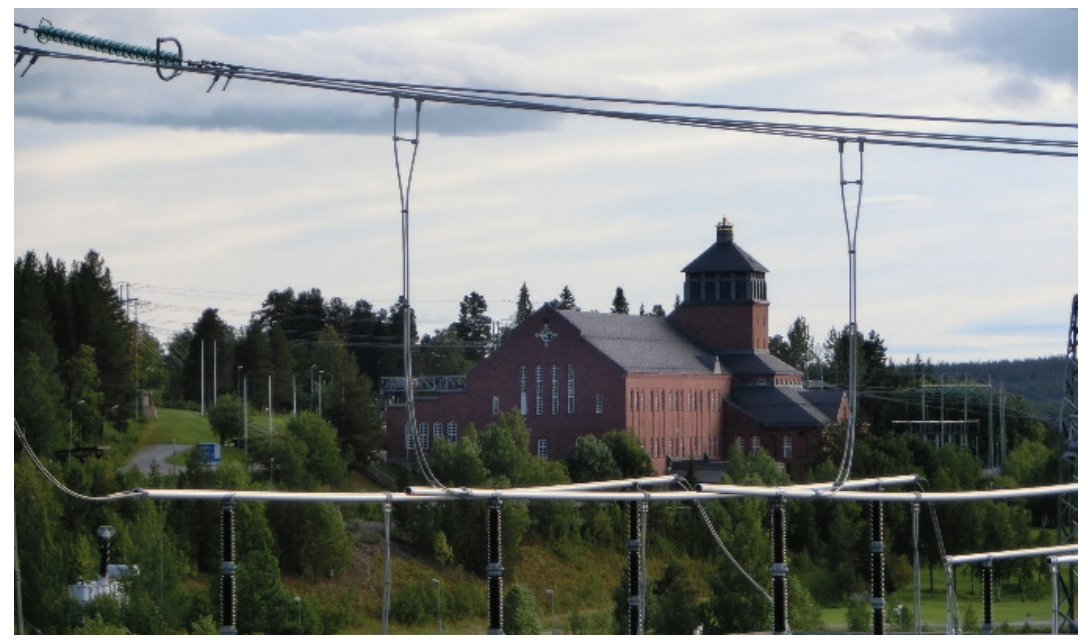

Figure 8 'Porjus cathedral'. Photograph by the author, 2013. 


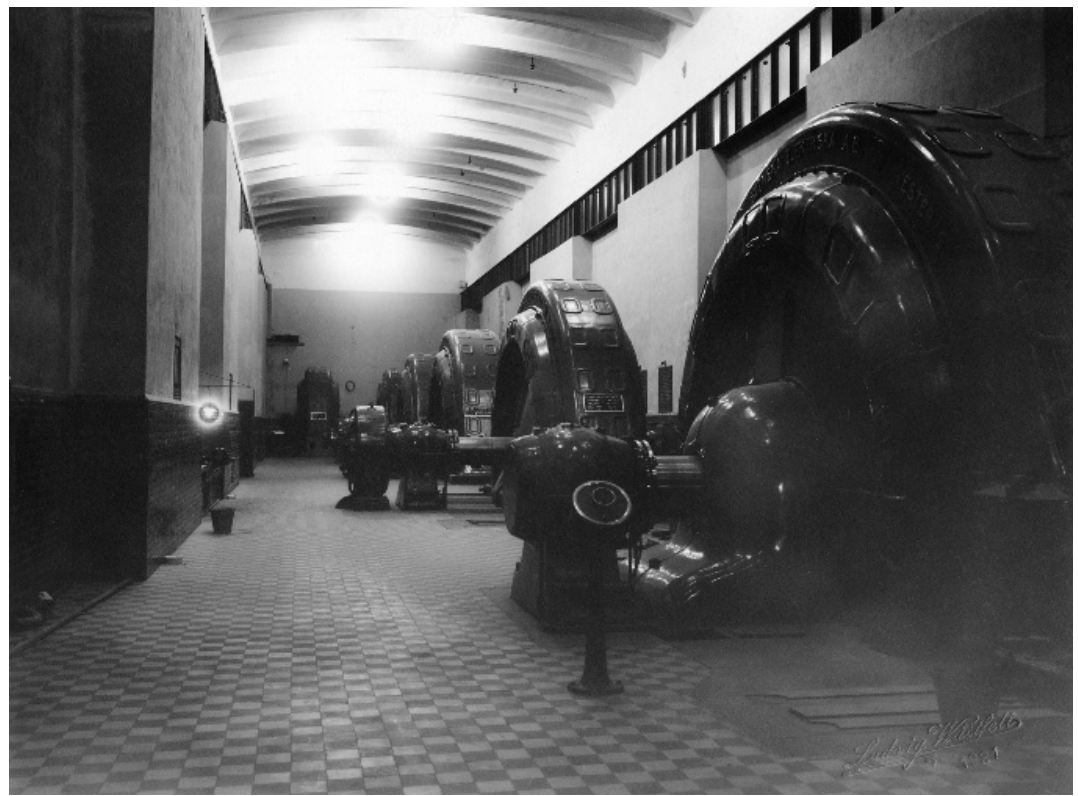

Figure 9 The machine hall in Porjus. Photograph: Ludvig Wästfelt, I92I. From: digitaltmuseum.se/O2IOI6338992/porjus-kraftverk-maskinsalen (29.0I.20I9).

as a heathen temple instead of a church; still, the depiction was no less sacrally saturated:

After having seen Porjus' machine hall, I think I can die without having seen an Indian or Japanese temple. Just as brightly dark as these are, so brightly glistening is the machine hall; just as denyingly mysterious Brahma's and Vishnu's temple halls are for Europeans, so open and pleasantly accessible this Swedish hall strikes us - not for the adoration, but for the exploitation of the new and coming god Electricity. ${ }^{55}$

Even more striking than this depiction was Per-Johan's description of the behaviour of the other guests inspecting the machine hall at the inauguration: 'In the bright, large hall, the inspecting travellers move, at first, with a certain awe or awkwardness in their voices and movements, but quickly they become more courageous, as it is hard for western Europeans to feel reverence for very long' ${ }^{56}$ Supposing we can trust Per-Johan's testimony here, the quote shows that the metaphor of the 
sacral was more than a trope; it was something that reached right into the habitus of the contemporaries, making them behave - if only for a short moment - as if they stood in an actual sacral building.

The second manifestation of the sublime in the discourse on Trollhättan and Porjus was the association with magical creatures. It might have been due to the circumstance that Porjus in the far Swedish north was associated with wilderness much more than Trollhättan, that a much richer fauna of these magical creatures inhabited the descriptions of Porjus power plant. ${ }^{57}$ The machine hall reminded commentators who visited it during construction of 'a modern Hall of the Mountain King' ${ }^{58}$ or of 'the workshop of the industrious black elves'. ${ }^{59}$ Per-Johan saw in the half-round generator bodies 'the giant backs of some monstrous primitive armoured lizards' ${ }^{60} \mathrm{He}$ also made it clear that these creatures were not just harmless zoo animals. In a description of the power plant's still empty distribution basin he once more demonstrated his eye for the details of the bodily movements of his company (Fig. IO):

It is a giant cave, a mastodon dwelling, with moisture, chill and half-light; lamps on a rope of pearls halfway up the cave send a few erratic rays up to the roof's mighty beam constructions and deep down to the damply glowing, concrete, jet-black floor and onto the walls of the cave ... Some of us descend into the basin and in the light of a low hanging lamp try to penetrate the cool and dark throat, but they recoil and desist from it. ${ }^{61}$

The hollow spaces, the tubes and wires in which the liquids and electrical currents flowed through the power plant, led many a commentator to describe the whole plant as a living organism. One of them, the Stockholm journalist Ernst Klein, 'in a somewhat daring comparison' called the distribution basin 'the power plant's stomach' ${ }^{62}$ From the basin ' $[\mathrm{t}] \mathrm{hrough}$ iron-clad throats, five metres in diameter, the monstrosity brought here by humans drinks the green, cold water, ${ }^{\prime}{ }_{3}$ which then reached the 'centre of the giant organism' and its 'power-producing organs, the turbines' ${ }^{64}$ In more commonplace metaphors the organicist imagery also found its way into the publications of the engineers, where the control room at Trollhättan could figure as 'the power plant's "brain". ${ }^{65}$ And Per-Johan, never at a loss for a joke, labelled the switchgear building as the 'heart' of Porjus, only to carry on: 'If the switchgear 


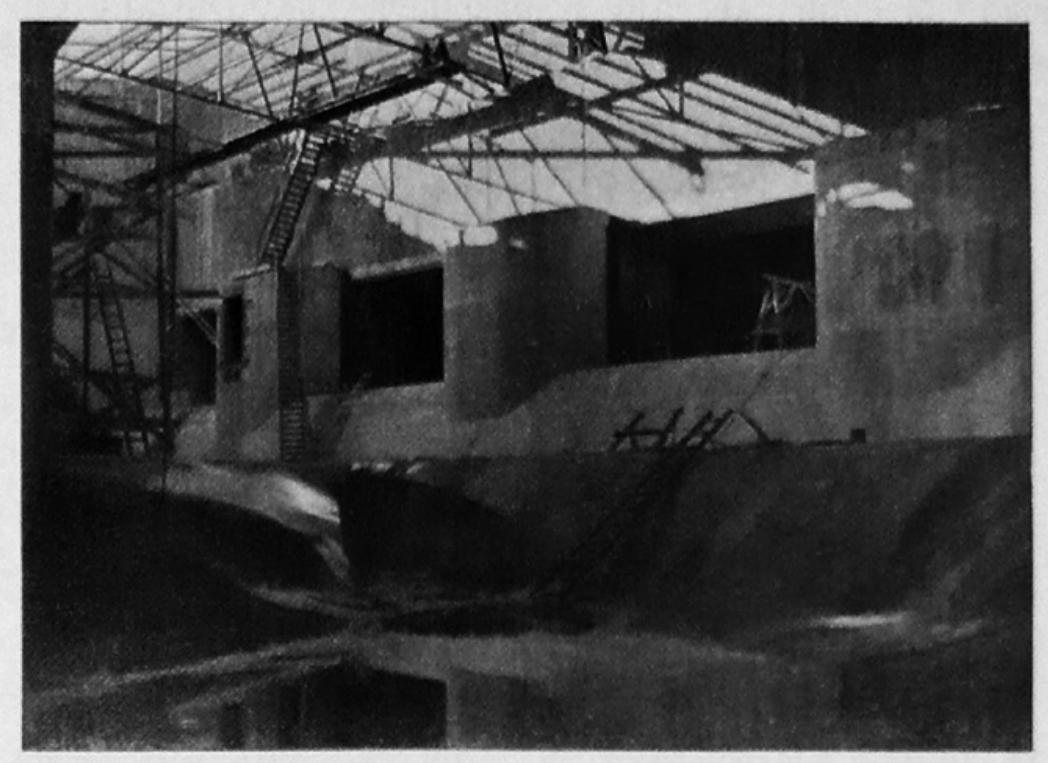

Fig. 24. INTERIÖR AF FÖRDELNINGSBASSÄNGRN, SÖDRA DELEN.

Figure Io 'Interior of the distribution basin, southern part.' From: Westerlind / Borgquist, 'Porjus Kraftverk', I07.

building can well be called the heart of Porjus, then the control room is the heart's brain. ${ }^{66}$

The most prominent example of a magical creature is certainly found at Trollhättan. Placed at the dam weirs, a large sculpture designed by Erik Josephson and executed by the sculptor Carl Eldh embodied a 'giant water sprite surfacing out of the water masses, who bears on his shoulders the bridge that is united here over the river' (Fig. I I). This was Josephson's own description of the sculpture, which was named Strömkarl (Water Sprite). According to one local historian, the sculpture soon went by the nickname 'victory monument' among the people of Trollhättan. ${ }^{67}$ This interpretation was quite in line with a sculpture draft found in Josephson's earlier designs that was to emblazon the machine hall's central projection and that depicted 'the natural force, bound by science and industry' ${ }^{68}$ Science and industry were embodied by two female figures identified by a book and a cogwheel, respectively, holding 


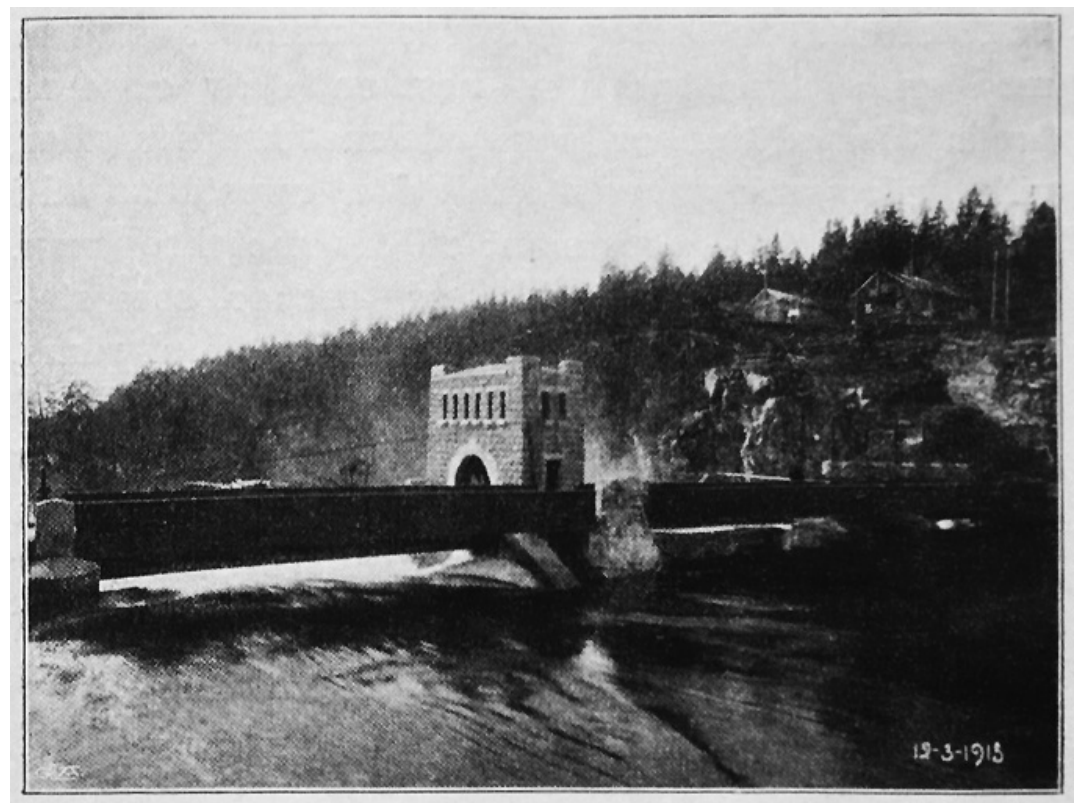

Figure I I Strömkarl bridge, I9I3. From: Kungl. Vattenfallsstyrelsen (ed.), Kungl. Vattenfallsstyrelsens utställning vid Baltiska utställningen i Malmö I9I4, 29.

an ogre-like figure between them that certainly resembled the Strömkarl sculpture which was eventually executed (Figs. I2 and I3). However, interpreting the latter sculpture simply as a more refined version of the former one overlooks the details in Josephson's description of the sculpture that characterized the Water Sprite as a 'surfacing giant', not quite fitting the imagery of a vanquished natural force.

The Water Sprite in Scandinavian folk tales was mostly found near running water or under bridges, embodying the unbound forces of water. According to Jochum Stattin's ethnological analysis of the figure, it was a creature that had a mediating position between nature and man and that showed itself especially in border situations and situations of transgression, supervising and sometimes even manipulating humans' behaviour towards nature and towards quasi-natural taboos. For instance, in many tales the Water Sprite would appear at a mill and block the water flow or even destroy the installations if the miller dared to grind flour on a holiday. ${ }^{69}$ Intriguingly, the Strömkarl sculpture in Trollhättan was placed at the base of a guard room from which the water levels in the Göta Älv were supervised and where discharge into 


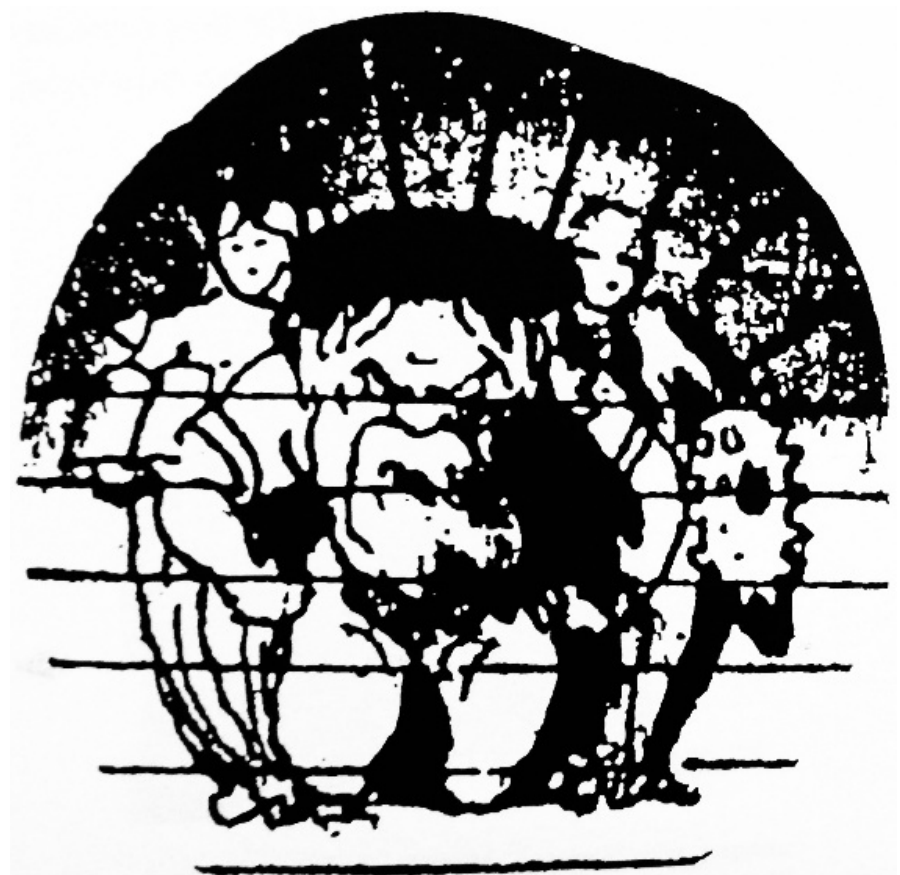

Figure I 2 The natural force, bound by science and industry. From a draft by Josephson, I907, enlarged in: Svensson, Strömkarlen, 59.

the old riverbed (and past the power plant) was regulated..$^{70}$ In doing so, Josephson charged the human guardsman's occupation with allegorical meaning: just like the water sprite, he would mediate between the force of the water and human demands. Additionally, the sculpture was placed precisely at the point where the Göta Älv first left its natural course and transgressed the border into a man-made riverbed. Whatever the precise meaning that Josephson intended here, it is clear that the interpretation as a 'victory monument' certainly does not do the complex constellation any justice. We may rather assume with art historian Lasse Brunnström that the Strömkarl must be understood as an 'admonition about the complexity of nature's exploitation'..$^{71}$

In these manifestations of the sublime we see, once more, a striking continuity not only between the imagery of the recreational landscape of the waterfall on the one hand and that of the productive landscape of the power plant on the other. We also see a certain persistence, even if 


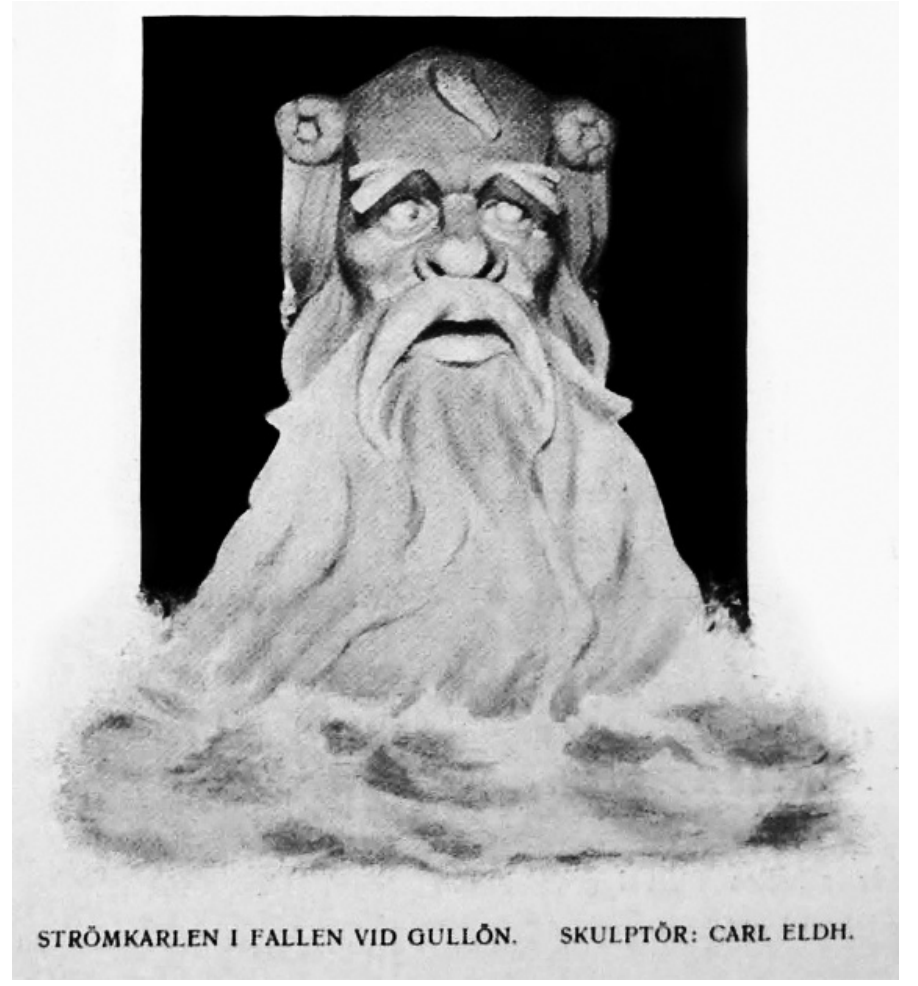

Figure I 3 'The Strömkarl in the falls at Gullön. Sculptor: Carl Eldh.' From: Josephsson, 'Statens kraftverk vid Trollhättan', 65.

in a rather folkloristic form, of the pre-modern 'magical landscape' that Orvar Löfgren has postulated. In his analysis of the 'technological sublime', David Nye has demonstrated that the sublime can be understood as a mode of perception through which the encounter with the new, the strange and the incomprehensible could be given tangible forms. As an example, Nye refers to the contemporaries of the first railroads, who 'could not decode the experience into familiar categories and therefore ... turned to the supernatural. ${ }^{\prime 2}$ In the case of the water power plant, a store of experience - the waterfall - was already at hand on which the experience of the new constructions could be modelled in the forms of the sublime.

To the contemporaries of the first plants, water power was strange and hard to comprehend, as commentators often stressed in their descriptions of the power plants. ${ }^{73}$ But water power plants not only posed an 
intellectual problem; the power of water and the power of electricity, combined in the plant, were often perceived as threatening. And they were. On the very same day that the power plant at Trollhättan was first put into operation in March I9I0, a twelve-year-old boy who had climbed onto the power lines near the plant was so gravely injured that both his arms had to be amputated. Newspaper headlines were alarmed and even overstated the facts: 'Yet another boy killed by electric power line'. ${ }^{74}$

Both the incomprehensibility and the threatening character of the power stations correspond well to the two manifestations of the technological sublime that I have examined here, the sacral and the monstrous. Perceiving the new power stations in the mode of the technological sublime made it possible for their contemporaries to appropriate their newness in an ambivalent way that allowed to acknowledge the anxiety caused by new technology and to incorporate it into a sensible narrative, without having to openly oppose technology. As Bernhard Rieger has demonstrated, drawing on case studies of ocean liners, air planes and cinema in Germany and Great-Britain between I 880 and I930, public opinion surprisingly often appropriated novel technologies in 'a variant of ambivalence that supported, rather than inhibited, public acceptance of further change'. ${ }^{75}$ This is equally true for our Swedish case.

And yet, the technological sublime could even do more than to foster acceptance. As David Nye has pointed out, one function of the technological sublime has been to render industrial labour invisible: 'Such descriptions implied automatic machinery and in effect eliminated workers from the landscape of production. ${ }^{2}{ }^{6}$ By conceptualizing the power plants as sacred places or even as living organisms with their own agency they were removed out of the sphere of human action altogether. Technical development was thereby stripped of its political character and eventually naturalized. It is here that one might start finding an answer to the question of why 'water power was somehow perceived as standing outside or above all parties'. ${ }^{77}$

\section{Rallying the Nation}

It was on the basis of this naturalization that a strong value could be attached to the water power plants at Trollhättan and Porjus, a value that was perceived as apolitical by contemporaries: the unity of the nation. 
'The specific advantage of the sublime', according to David Nye, is that 'as a shared emotion ... it is beyond words' ${ }^{\prime 8}$ and has therefore lent itself well as a foundational experience for national identity in the American case that he describes. That this equally holds true for our Swedish case can be observed, for instance, in the inauguration ceremonies that I already touched upon in the introduction. At Trollhättan, the King inspected the still ongoing canal works, where he was awaited by the engineers 'and some of the workshop's labourers', to whom he then spoke:

I especially want to thank the engineers of the canal works, as well as the workers from highest to lowest. I give you my warmest thanks for the zeal and the dutifulness that you have consistently shown in the execution of these grand works, and I ask you at the same time, to deliver my warmest greetings and thanks to your absent comrades. ${ }^{79}$

At the inauguration in Porjus, Fredrik Vilhelm Hansen praised all parties involved in the planning, the decision processes and the completion of the power plant, not forgetting to 'recall ... the large workforce and to use the opportunity to testify to their zeal and interest in the work and the good relationship that has prevailed between them and those in command, which has honoured both parts. ${ }^{, 80}$

Only one 'big deception' disturbed the collective enthusiasm at the inaugurations. As the correspondent for Dagens Nyheter at Porjus wrote, it was the fact 'that the King of Porjus, the settler Lasse Olsson, was notably absent.' This referred to the previous owner of the land at Porjus, Erik Abraham Olofsson Rim, who called himself Olsson (but not Lasse) and who had sold his land to the State in I 909 after long negotiations. Subsequently however, he found that he had been deceived and by way of action attempted to retrieve parts of his land that he reckoned he had not sold. He lost all cases and the relationship between him and the State Power Board grew increasingly strained. Olsson's case must probably be understood as a 'culture shock', as Nils Forsgren has suggested: 'A person who has lived all his life literally off the beaten track is suddenly confronted with the whole state administration with its juridical expertise in front. ${ }^{81}$ This was not the perspective taken by the correspondent of Dagens Nyheter: 'The King of Porjus could not tolerate that civilization and culture have so strongly taken hold in 
the wasteland of Lappland as it has now happened without getting any compensation for it, without receiving the chinking valuta for which he had hoped. ${ }^{{ }^{82}}$ As a Sámi, Olsson apparently was not part of the nation for whose benefit the power plant had been built. To the Stockholm correspondent, Olsson's absence appeared ungrateful, a sign of selfishness that was opposed to national unity.

The nationalist symbolism did not stop at the fleeting representations of the two plants, however. With prominent crown ornaments both in Trollhättan and in Porjus (I have mentioned the Royal crown atop Porjus' plant), the architectural designs themselves acted as durable national symbols. They even embodied a unified nation: to choose burnt brick as façade material, as in Porjus, was not a mere material decision for a Stockholm architect around I900, like Josephson. The unplastered brick face with its lively materiality was around that time seen as an ideal means to give buildings a genuinely Swedish appearance. And even if building in brick had a longer tradition only in the very southern parts of Sweden, countless representational buildings were erected all over the country with proudly Swedish brick façade during the first decennia of the twentieth century. ${ }^{83}$ In the case of both Trollhättan and Porjus contemporaries did not tire to mention that the building materials (just as the turbines and electrical installations, as well as the workforce) were of Swedish origin; the bricks for Porjus came all the way from Helsingborg in southern Sweden, the granite in Trollhättan was supplied by the company Hilleviken in Stockholm. This differs from the material politics of water power plants that were built for instance in Germany during the same time, where a high value was set on using local building materials, mined near the construction site, in order to embed the installations into the local landscape. ${ }^{84}$ In our Swedish cases, by contrast, the aim was clearly to embed them into a single national landscape. ${ }^{85}$

This rhetoric of national rallying must be seen as a reaction to a crisis in Swedish national identity that peaked in the early years of the twentieth century. In I905 the personal union between the kingdoms of Norway and Sweden was dissolved at the instigation of the Norwegian parliament, shattering any hopes that Sweden would ever return to its territorial grandeur of the seventeenth century, the loss of which still haunted the national spirit. ${ }^{86}$ The perceived loss of territorial integrity was further aggravated by two tendencies of disintegration. On the one 
hand, emigration from Sweden to the USA culminated around I90o. The departure of ten thousands of predominantly young, male Swedes per year was perceived by contemporaries as a terrifying 'bloodletting', a stream of vital workforce running out of the country, weakening its position in international competition. On the other hand, the threat of class struggle posed by an emerging labour movement seemed to further destabilize the already waning integrity of the Swedish people. ${ }^{87}$ Indeed, during the construction of both plants workers had repeatedly gone on strike for better payment, better food, better occupational safety and shorter working time. ${ }^{88}$ This circumstance, of course, did not figure in the inaugurations' ceremonials.

Instead, the discourse around Trollhättan and Porjus constructed these plants as remedies to the perceived national crisis. If only the 'flowing millions' hitherto running to waste could be harnessed quickly, many water power enthusiasts urged during the years immediately before the construction of Trollhättan's plant. ${ }^{89}$ The equally harmful stream of young blood leaving the country for America could then be redirected, healing the 'great loss that the country suffers because thousands of young men emigrate every year as a result of lacking job opportunities. ${ }^{90}$ A new life would then be instilled into Swedish industry that would benefit the whole people, and no longer the purses of individuals or foreign investors. The whole scope of benefits was summarized in I9I 6 by Fredrik Vilhelm Hansen, then the director-general of the State Power Board, after the construction works had been finished and started doing their charm:

Reduced dependency on abroad, increased vigour and increased comfort in the country, increased income for the treasury, increased earnings for the individual, here are the advantages that more than well outweigh the high capital disbursements and that urge for the further development of the power plant, for the further exploitation of the natural splendour that generous higher powers have given to the Swedish people in the white coal of the Göta Älv!91

\section{Conclusion}

Drawing this story to a close, I concede that the exploitation of water power was in fact a hotly contested political topic, especially in the 
case of Trollhättan where plans for exploitation started much earlier than in Porjus. The daily press and engineering journals like Teknisk Tidskrift were brimming with articles about the question whether the State should engage in a centrally planned exploitation or whether the field should be left to private interest, about the legal ownership of the waterfall and the surrounding land, about amendments to Swedish water law that was perceived to be outdated, as well as about the technically most efficient ways of power production. ${ }^{22}$ In light of rising international economic competition, dependency on coal imports and foreign investments in the harnessing of Sweden's waterfalls, a strong urgency marked the debates. However, there was one point in these debates that all parties agreed on. Water power had to be exploited. Fundamental opposition in this regard, if at all, could only be expected from nature lovers, as the occasional criticism from the STF and SNF showed and as the Swedish public could observe in several contemporary debates taking place abroad, for instance the Hetch Hetchy controversy in California or the founding of the Bund Heimatschutz for the protection of the Laufen in the river Rhine in Germany. ${ }^{93}$ However, Swedish nature lovers remained strikingly mute and framed the issue of landscape change at the waterfalls of Trollhättan and Porjus as a 'national-aesthetic' matter that could be resolved, as I have shown, with an imagery of the sublime. ${ }^{94}$

Ultimately, one could argue, the interests of water power enthusiasts and nature lovers converged. Just like the water masses were to be developed for the benefit of the nation through the construction of power stations, they were also to be developed in order 'to lead the stream of tourists to Sweden', as was the aim of the STF at Trollhättan. More often than not, the rhetoric used by the Association as an argument for making the landscape accessible to the public strikingly resembled the rhetoric of engineers. What the latter measured in increased horse power and in increased employment numbers, the former measured in increased visitor numbers. The harnessing of unused potentials, the collection of all forces and the increase of productivity was the rallying cry put forward collectively by all parties involved in the public discourse about the early water power stations. In their productiveness, nature, nation and the dam could be united in sublime harmony.

Perhaps more than in David Nye's American cases, the sublime thus became a central mediator of a national identity crisis in our Swedish 
case. ${ }^{95}$ The sublime water power landscapes of Trollhättan and Porjus became places where Sweden's national narratives were rewritten and where Sweden's modernization from a poor agrarian country to a highly industrialized country was constructed, both materially and in the public imagination.

\section{Notes}

I Parts of the research for this paper were made possible by generous funding from the German Federal Environmental Foundation (DBU) and the warm hospitality of the Division of History of Science, Technology and Environment at the Royal Institute of Technology (KTH) in Stockholm. Furthermore, the author wishes to thank the anonymous reviewers for their helpful comments.

2 Thor Högdahl, “'Döda fallen" vid Trollhättan: Norra Europas praktfullaste vattenfall förintade', Sveriges Natur: Svenska Naturskyddsföreningens Årsskrift (1923) 193. All translations from Swedish by the author.

3 Ibid., I97. The article was a reprint of an article in the conservative newspaper Svenska Dagbladet, 6 May 1923.

4 'Know your country!' is still STF's motto today. On the history of STF and its ideas on nature, landscape and conservation see Erik ErlandsonHammargren, Från alpromantik till hembygdsromantik: Natursynen $i$ Sverige från I885 till 19I5, speglad i Svenska turistföreningens årsskrifter och Nils Holgerssons underbara resa genom Sverige (Hedemora, 2006); Orvar Löfgren, 'Rational and Sensitive: Changing attitudes to Time, Nature, and the Home', in Jonas Frykman and Orvar Löfgren (eds), Culture builders: A Historical Anthropology of Middle-Class Life (New Brunswick, I987) and Sverker Sörlin, Framtidslandet: Debatten om Norrland och naturresurserna under det industriella genombrottet (Stockholm, I988). In its early years the SNF had close personal and ideological ties with the STF. For instance, the associations shared their chairman between I9I 2 and I9I7; Désirée Haraldsson, Skydda vår natur! Svenska naturskyddsförenigens framväxt och tidiga utveckling (Lund, 1987) I79.

5 Gustaf Retzius, 'Vid Trollhättan', Svenska Turistföreningens Årsskrift (I896) 53.

6 Vattenfall's early history and construction works have been analyzed in Mats Fridlund, Den gemensamma utvecklingen: Staten, storföretaget 
och samarbetet kring den svenska elkrafttekniken (Stockholm, Stehag, I999); Eva Jakobsson, Industrialisering av älvar: Studier kring svensk vattenkraftutbyggnad I900-19I8 (Göteborg, 1996); Staffan Hansson, Porjus: En vision för industriell utveckling i övre Norrland (Luleå, I994).

7 Göteborgsposten, 3I October I9IO.

8 'Porjus', Teknisk Tidskrift: Veckoupplagan 45:8 (I9I5) 6I. The notion that the inaugurations of these early power plants were inappropriate to the grandeur of the constructions was still repeated in the memoirs of Gösta Malm, who had led the constructions at Trollhättan: Gösta Malm, I min krafts dagar (Stockholm, I963) 64.

9 Dagens Nyheter, 9 February 19I5. The same article could be found, in slightly shortened versions, in Svenska Dagbladet and Göteborgsposten of the same date.

Io Per-Johan: 'I Porjus underbara värld', Norrskensflamman, I2 February I9I5.

I I Dagens Nyheter, 9 February I9I5.

I2 See Löfgren, 'Rational and Sensitive', 42-57, who speaks of a landscape of production and a landscape of consumption. The dichotomy has more recently been repeated by Sverker Sörlin, 'Upptäckten av friluftslandskapet', in Klas Sandell and Sverker Sörlin (eds), Friluftshistoria: Från 'härdande friluftslif' till ekoturism och miljöpedagogik (Stockholm, 2000) 2 I.

I3 Evert Vedung and Magnus Brandel, Vattenkraften, staten och de politiska partierna (Nora, 200I) 36.

I4 From the I950s on, the exploitation of rivers was faced with strongly increasing environmental protest in Sweden, which has lead many historians to degrade the debates of the preceding half century to a mere prehistory of the post-war conflicts. See for instance Kjell Nilsson, 'Where industry meets nature: How public concern has influenced the design of Swedish industrial landscapes during the 2oth century', Landscape and Urban Planning 23 (1992), doi:I0.Ior6/or69-2046(92)90062-5. On the post-war conflicts see Jonas Anshelm, Vattenkraft och naturskydd: En analys av opinionen mot vattenkraftutbyggnaden i Sverige 1950-1990 (Linköping, I992).

I5 Karl Baedeker, Norway and Sweden: Handbook for travellers, 4th ed. (Leipzig, I889) 29 I.

I6 'Årsberättelse från Trollhättans kretsförening för år I896', Svenska Turistföreningens Årsskrift (I 897) XXXVIII-XXXIX.

I7 Retzius, 'Vid Trollhättan', 4I. 
I8 Ibid., 52.

I9 For a brief summary see Arne Kaijser and Karel Mulder, 'The dynamics of technological systems integration: Water management, electricity supply, railroads and industrialization at the Göta Älv', Technology in Society 39 (20I4), 90-I, doi:Io.IoI6/j.techsoc.20I3.I I.003.

20 Retzius, 'Vid Trollhättan', 53.

2 I In 'Trollhättans kretsförenings årsberättelse för I90I', Svenska Turistföreningens Årsskrift (I902) 4I 2.

22 In the summary of a meeting in which the plans for a power plant at Trollhättan were discussed: Johan G. Richert, 'Trollhättans Vattenkraft', Teknisk Tidskrift: Almänna avdelningen 33:2 I (I903) I 85.

23 Gösta Malm, 'Trollhätte kraftverk: Vatten- och husbyggnadder samt turbiner', in Kungl. Vattenfallsstyrelsen (ed.), Trollhättan: Dess kanal-och kraftverk. Historik och beskrifning 3: I (Stockholm, I9I2) I35.

24 Erik Josephsson, 'Statens kraftverk vid Trollhättan', Teknisk Tidskrift: Arkitektur 4I (I9I I) 65.

25 Fredrik Svenonius, 'Vattendragens utnyttjande och skyddandet af naturens skönhet', Sveriges Natur: Svenska Naturskyddsföreningens Arsskrift (I9I I) 82 .

26 Retzius, 'Vid Trollhättan', 42, 47, 49.

27 See Eduard L. Albert, 'Trollhättan: De nya anläggningarna nedanför Kopparklinten och Trollhättan såsom nationalpark', Svenska Turistföreningens Årsskrift ( I 905) I 72; Hans O.Elliot, 'Trollhättesträndernas bebyggande', in Kungl. Vattenfallsstyrelsen (ed.), Trollhättan: Dess kanaloch kraftverk. Historik och beskrifning 2:2 (Stockholm, I9I6) 3-5.

28 Karl Starbäck, 'Naturskydd: Föredrag vid Baltiska Ingenjörskongressen i Malmö den I6 juli I9I4', Teknisk Tidskrift. Veckoupplagan 45:2 (I9I5) I4.

29 See Åsa Össbo and Patrik Lantto, 'Colonial tutelage and industrial colonialism: Reindeer husbandry and early 2oth-century hydroelectric development in Sweden', Scandinavian Journal of History 36:3 (20 I I ) 33032, doi:Io.I080/03468755.20 I I.580077; Åsa Össbo, Nya Vatten, dunkla speglingar: Industriell kolonialism genom svensk vattenkraftutbyggnad $i$ renskötselområdet I9IO-I968 (Umeå, 2014) 75-7.

30 Indeed, the waterfalls in Porjus were described in detail and entirely measured for the first time only in I904, see Axel Hamberg, 'Porjuskatarakterna och en forsfärd på Lule Älf', Svenska Turistföreningens Årsskrift (I905).

3 I Sörlin, Framtidslandet.

32 Karl-Erik Forsslund: 'Från striderna vid gränsen: Ur en resdagbok', Sveriges Natur: Svenska Naturskyddsföreningens Årsskrift (1912) 70. 
What Forsslund feared was not the loss of the waterfalls at Porjus themselves, but rather how the constructions might affect the Stora Sjöfallet national park further upstream. When the construction of another dam within the national park was decided in parliament without any debate in I9I9, Högdahl joined Forsslund's open criticism in Thor Högdahl, 'Stympandet av Stora Sjöfallets nationalpark: Ett sorgligt nederlag för naturskyddet', Sveriges Natur: Svenska Naturskyddsföreningens Årsskift (1920), I37-I40. Högdahls publication provoked a crisis within the SNF that showed that the vast majority of members preferred a compromising strategy over the radical preservationism endorsed by Högdahl and Forsslund. See Haraldsson, Skydda vår natur!, I88-94.

33 Eira Hellberg, 'Porjus: Ett stycke svensk odlingshistoria', Ord och Bild ( I9I7). The Swedish term odling comprises all forms of cultivation, from land reclamation and farming to intellectual education. Hellbergs account was based on a more nuanced article by her colleague Ernst Klein, 'Där urtid och framtid mötas: Bilder och anteckningar från ett besök i Porjus sommaren I9I3', Svenska Turistföreningens Årsskrift (I9I4).

34 Hellberg, 'Porjus', 420, 428, 430, 420-I (in this order).

35 Kungl. Vattenfallsstyrelsen (ed.), Redogörelse för arbetena med Porjus kraftverksbyggnad intill utgången af år I9I I (Stockholm, I9I3) 49.

36 Albert Westerlind and Waldemar Borgquist, 'Porjus Kraftverk', Teknisk Tidskrift: Veckoupplagan 45:I2 (I9I5) 99; Klein, 'Där urtid och framtid mötas', 75; Ernst Klein, 'En tyglad vildmarksjätte - Porjusforsen i statsjänst', Idun 28:8 (I9I5) I 26.

37 Eva Jakobsson, 'Industrialized Rivers: The Development of Swedish Hydropower', in Arne Kaijser and Marika Hedin (eds), Nordic Energy Systems: Historical Perspectives and Current Issues (Canton MA, I995) 55.

38 See Ibid.; Eva Jakobsson, 'Industrialization of Rivers: A Water System Approach to Hydropower Development', Knowledge, Technology, \& Policy I4:4 (2002), doi:I0.I007/sI2I30-002-IOI4-O and in more detail Jakobsson, Industrialisering av älvar, I I I-69.

39 Kungl. Vattenfallsstyrelsen (ed.), Kungl. Vattenfallsstyrelsens utställning vid Baltiska utställningen $i$ Malmö I9I4: Grupp C inom svenska ingenjörers och arkitekters avdelning (Stockholm, I9I4) 25; Königliche Wasserfallverwaltung (ed.), Die Staatlichen Kraftwerke Schwedens I92 I: Allgemeine Beschreibung (Uppsala, I92 I) I I, along with its Swedish and English translations.

40 G. H[olmberge]r., 'Trollhättan just nu', Teknisk Tidskrift: Veckoupplagan 42:22 (I9I2) 207. 
4I The book was published in Swedish, English and German; I quote from the German edition here: Königliche Wasserfallverwaltung, Die Staatlichen Kraftwerke Schwedens I92 I, I4.

42 Klein, 'Där urtid och framtid mötas', 7I. See John Åkerlund, “"Vackra Verk": Samfundets för Hembygdsvård utställning i Stockholm hösten I924', Sveriges Natur: Svenska Naturskyddsföreningens Årskrift (I925) IOO.

43 Klein, 'Där urtid och framtid mötas', 78. Klein was not openly critical, but well aware of the problematic character of the encroachments. Similar formulations from conservationists can be found in: 'Naturskyddsfrågan inför Baltiska ingenjörskongressen: Naturskyddet och Industrien', Sveriges Natur: Svenska Naturskyddsföreningens Arsskrift (I9I5) I64 and Amalia Björck, 'Trollhättans hästar', Ord och Bild 24 (I9I 5) 34.

44 Göteborgsposten, 3 I October I9Io.

45 F. W., 'Svenska Turistföreningens Medaljörer', Svenska Turistföreningens Årsskrift (19I4) 377.

46 Malm, 'Trollhätte kraftverk', 86.

47 Harald Johnsson, 'I automobil genom Sverige med "Julstämmnings" turistfärd: II. Göteborg - Lilla Edet - Trollhättan - Uddevalla - Åmål', Vecko-Journalen 3:24a (I9I2) 378 (both quotes).

48 As codified in Edmund Burke's Philosophical Enquiry into the Origin of our Ideas of the Sublime and the Beautiful in 1757.

49 Retzius, 'Vid Trollhättan', 52. 'Piety' was demanded both by conservationists and engineers: Starbäck, 'Naturskydd', I3; H[olmberge]r., 'Trollhättan just nu', 207.

50 The metaphor of the sacral was and is still today prominent in discourse on hydroelectricity and technology in general, see for instance: Christian Schwarke, Technik und Religion: Religiöse Deutungen und theologische Rezeption der Zweiten Industrialisierung in den USA und in Deutschland (Stuttgart, 20I4) or, on water power specifically, Michael Mende, "“Denkmäler von Adel und Kraft": Wassermühlen und Wasserkraftwerke zwischen Nutzung und Erhalt', Kultur \& Technik I3:4 (I989), 2 I6-23. A critical assessment of the sacral metaphor in recent heritage debates is found in Hermann Sturm, Industriearchitektur als Kathedrale der Arbeit: Geschichte \& Gegenwart eines Mythos (Essen, 2007).

5I Malm, 'Trollhätte kraftverk', 84.

$52 \mathrm{He}$ also referred to an emerging tradition of temple and church-inspired power plant architecture. See Lasse Brunnström, Estetik och ingenjörskonst: Den svenska vattenkraftens arkitekturhistoria (Stockholm, 200 I) I68-86. 
53 In all newspapers reporting on the inauguration on 9 February I9I5 (see note 9).

54 Klein, 'Där urtid och framtid mötas', 73.

55 Per-Johan: 'I Porjus underbara värld'.

56 Ibid.

57 This might also explain to some extent why the fauna of magical creatures outside Scandinavia seems to be mainly represented by the famous fée electricité. For a subtle analysis of this allegory see Ulf Otto, 'Enter Electricity: An Allegory's Stage Appearance between Verité and Varieté', in: Centaurus 57:3 (2015) I92-2 I I.

58 Forsslund, 'Från striderna vid gränsen', 70.

59 Klein, 'Där urtid och framtid mötas', 73.

6o Per-Johan: 'Slutkapitel om Porjus', Norrskensflamman, I6 February I9I5.

6I Per-Johan: 'Hur Porjus upptäcktes', Norrskensflamman, I I February I9I5.

62 Klein, 'Där urtid och framtid mötas', 72.

63 Klein, 'En tyglad vildmarksjätte - Porjusforsen i statsjänst', I 26.

64 Klein, 'Där urtid och framtid mötas', 73.

65 Einar Cronvall, 'Trollhätte kraftverk: Kraftsationens elektriska utrustning jämte därtill hörande anläggningar samt det elektriska ledningsnätet m. m.', in Kungl. Vattenfallsstyrelsen (ed.), Trollhättan: Dess kanal-och kraftverk. Historik och beskrifning, 3:2-3 (Stockholm, I9I2) 68.

66 Per-Johan: 'I Porjus underbara värld'.

67 Ove Svensson, Carl Eldhs Strömkarlen: Symbolen, myten och motivet. En berättelse om Strömkarlens tillblivelse och gestaltning (Trollhättan, I999) 75.

68 In Josephson's words in a letter to F. V. Hansen, 5 December I906, quoted from Brunnström, Estetik och ingenjörskonst, I 25.

69 See Jochum Stattin, Näcken: Spelman eller gränsvakt?, 2nd ed. (Stockholm, I992) 42-7.

70 See Malm, 'Trollhätte kraftverk', I2.

7I Brunnström, Estetik och ingenjörskonst, 35. Sadly, without any further explanation.

72 David E. Nye, American Technological Sublime (Cambridge MA, I994) 55.

73 See: Per-Johan: 'Hur Porjus upptäcktes'; Klein, 'Där urtid och framtid mötas', 63. As Bernhard Rieger has pointed out, the denial of all comprehension when confronted with new technology formed also part of a topos of awe, see Bernhard Rieger, "Modern Wonders": Technological Innovation and Public Ambivalence in Britain and Germany, I890s to I933', History Workshop Journal 55 (2003) I60, doi: I0. I093/hwj/55. I.I 52. 
74 Dagens Nyheter, 26 March I9Io. See also Göteborgsposten, 26 March I9IO.

75 Rieger, 'Modern Wonders', I 54.

76 Nye, American Technological Sublime, i I 8.

77 Vedung and Brandel, Vattenkraften, staten och de politiska partierna, 36.

78 Nye, American Technological Sublime, xiv.

79 As quoted in Göteborgsposten, 3 I October I9I0. My emphasis.

80 As quoted in Dagens Nyheter, 9 February I9I 5.

8I Nils Forsgren, Porjus: Pionjärverket $i$ ödemarken (Porjus, Vällingby, I982) 2 I. For more context, see Össbo and Lantto, 'Colonial tutelage', 330-2.

82 Dagens Nyheter, 9 February I9I 5.

83 Eva Eriksson, 'Internationella impulser och nationell tradition: I900-I5', in Claes Caldenby (ed.), Att bygga ett land: I9oo-talets svenska arkitektur (Stockholm, I998) 28-9.

84 See Jörg Stabenow, 'Staumauer und Monument: Die Talsperre Klingenberg, ein Werk des Architekten Hans Poelzig', Architectura 27 ( 1997), I93 and Fabian Zimmer, "Gefesselte Naturkräfte": Zur filmischen Inszenierung von Wasserkraft und Modernisierung', in Philipp Osten et al (eds), Das Vorprogramm: Lehrfilm / Gebrauchsfilm / Propagandafilm / unveröffentlichter Film in Kinos und Archiven am Oberrhein I900-1970. Eine französisch-deutsche Vergleichsstudie (Heidelberg, Strasbourg, 20I5), I35-6.

85 See also Mats Fridlund, 'De nationalistiska systemen: Konstruktion av teknik och svenskhet kring sekelskiftet I900', in Pär Blomkvist and Arne Kaijser (eds), Den konstruerade världen: Tekniska system i historiskt perspektiv (Stockholm, I998) 90, who has interpreted the power plants as expressions of a new 'industrial nationalism'.

86 There is general agreement on this turning point in Swedish historiography, see for instance Fridlund, Den gemensamma utvecklingen, 40-6; Jakobsson, Industrialisering av älvar, 70; Sörlin, Framtidslandet, 94-7; Aant Elzinga, Andrew Jamison and Conny Mithander, 'Swedish Grandeur: Reformulations of the Great-Power Project', in Mikael Hård and Andrew Jamison (eds), The Intellectual Appropriation of Technology: Discourses on Modernity, I900-1939 (Cambridge, London, I998).

87 On both points see Nils Edling, Detfosterländska hemmet: Egnahemspolitik, småbruk och hemideologi kring sekelskiftet I900 (Stockholm, I996) I90-203. 
88 The strikes at Trollhättan are described in Malm, 'Trollhätte kraftverk', I37-8. The situation in Porjus is described in Hansson, Porjus, I6I-8.

89 This imagery was frequently used by water power enthusiasts calling for a quick start of exploitation, see Fredrik V. Hansen, 'Några synpunkter i fråga om vattenkraftens tillgodogörande i Sverige', Teknisk Tidskrift: Almänna avdelningen 39:Specialnummer ( I909) I; Sven Lübeck, 'Svensk vattenkrafts utnyttjande', Teknisk Tidskrift: Veckoupplagan 42:4 (I9I2) 29.

90 Eduard L. Albert, 'Om tillgodogörandet af vattenkraften i Trollhättan', Teknisk Tidskrift: Almänna avdelningen 34:20 ( I904) 45.

9I Fredrik V. Hansen, 'Trollhätte kanal- och vattenverk under kronans hägn', in Kungl. Vattenfallsstyrelsen (ed.) Trollhättan: Dess kanal- och kraftverk. Historik och beskrifning, 2:I (Stockholm, I9I6) 24I.

92 These public debates among a relatively small group of system builders have been examined in detail by Jakobsson, Industrialisering av älvar and Fridlund, Den gemensamma utvecklingen, chapters 2-4. A selection of newspaper clippings from the debate around Trollhättan is documented in Charlie Cederholm, Till minnet av Vilhelm Hansen. Trollhättechef I898-1908, Vattenfallschef I909-28: Så föddes Statens Vattenfallsverk. Förhistorien I898-1908 (Vällingby, I979). The debates around Porjus focused more on the scope of the constructions and their precise location, as described in Hansson, Porjus.

93 For the 'battle over Hetch Hetchy' see for instance Robert W. Righter, The battle over Hetch Hetchy: America's most controversial dam and the birth of modern environmentalism (Oxford, 2008). For the damming of the Laufen see Ulrich Linse, "Der Raub des Rheingoldes": Das Wasserkraftwerk Laufenburg', in Ulrich Linse, Reinhard Falter, Dieter Rucht and Winfried Kretschmer (eds), Von der Bittschrift zur Platzbesetzung: Konflikte um technische Großprojekte. Laufenburg, Walchensee, Wyhl, Wackersdorf (Berlin, Bonn, I988) I I-62.

94 Albert, 'Trollhättan', I79.

95 This is not to say that the Swedish case is unique, however. The cases of Hetch Hetchy or the Laufen should not hide the fact that the sublime could act as an essential mediating force also in the US or in Germany, for example. See the multitude of examples presented by Nye, American Technological Sublime or the argument in David Blackbourn, The Conquest of Nature: Water, Landscape and the Making of Modern Germany (New York, London, 2006) I95-6. Rather, I would argue that the Swedish case can be used as a model following which the social function of the sublime 
or what Nye calls the 'politics of perception' can be further explored; Nye, American Technological Sublime, xvi.

\section{About the Authors}

Fabian Zimmer is a $\mathrm{PhD}$ student at the Rachel Carson Center for Environment and Society in Munich. His research focuses on the cultural history of modernity in Europe, which he explores through the history of technology, environmental history, visual and architectural history and the history of science and medicine. He has worked as a research assistant at the Institute for History and Ethics of Medicine at Heidelberg University and was a guest researcher at the division of History of Science, Technology and Environment at the KTH in Stockholm in 2018 and at the German Historical Institute in Paris in 2019. In 2017 he was awarded the Georg Agricola Society's Early Career Researchers Award for his MA thesis. E-mail: fabian.zimmer@rcc.lmu.de 